\title{
Thiamine hydrochloride: An efficient catalyst for one-pot synthesis of quinoxaline derivatives at ambient temperature
}

\author{
OMPRAKASH B PAWAR $^{\mathrm{a}, *}$, FULCHAND R CHAVAN ${ }^{\mathrm{b}}$, VENKAT S SURYAWANSHI ${ }^{\mathrm{a}}$, \\ VISHNU S SHINDE ${ }^{\mathrm{a}}$ and NARAYAN D SHINDE ${ }^{\mathrm{a}, *}$ \\ ${ }^{a}$ Department of Chemistry, Shri Chhatrapati Shivaji College, Omerga 413 606, India \\ a Department of Chemistry, Vasantrao Naik College, Aurangabad 431 005, India \\ e-mail: drnds09@rediffmail.com; obpawar@ rediffmail.com
}

MS received 30 December 2011; revised 5 May 2012; accepted 8 June 2012

\begin{abstract}
Quinoxaline derivatives have been synthesized in high to excellent yields in the presence of thiamine hydrochloride $\left(\mathrm{VB}_{1}\right)$ as an inexpensive, non-toxic and metal ion free catalyst at ambient temperature.
\end{abstract}

Keywords. Quinoxalines; aryl-1,2-diamines; 1,2-diketones; thiamine hydrochloride.

\section{Introduction}

Quinoxaline and its derivatives have been received much attention because of their wide range of pharmacological and therapeutic properties. ${ }^{1-8}$ They have also been found applications in organic semiconductors, ${ }^{9}$ dyes, ${ }^{10}$ electroluminescent materials, ${ }^{1}$ cavitands, ${ }^{11}$ building blocks for the synthesis of anion receptors $^{12}$ and DNA cleaving agents. ${ }^{12}$ Therefore, several methods for the synthesis of quinoxalines have been reported in the literature. ${ }^{13-32}$ However, some of these reported methods are associated with one or more disadvantages such as harsh reaction conditions, use of expensive reagents, use of environmentally toxic reagents and use of large amount solid supports, which result in the generation of a large amount of toxic waste. Thus, several previous methods have been excluded from practical applications due to environmental and economic considerations. Hence, there is still a need to develop efficient methods for the synthesis of quinoxaline derivatives.

Thiamine hydrochloride is a non-toxic, inexpensive, stable, eco-friendly and metal ion free catalyst. Thiamine hydrochloride has been used as powerful catalyst for various organic transformations. ${ }^{33-35}$ The structure of thiamine hydrochloride contains a pyrimidine ring and a thiazole ring linked by a methylene bridge (figure 1).

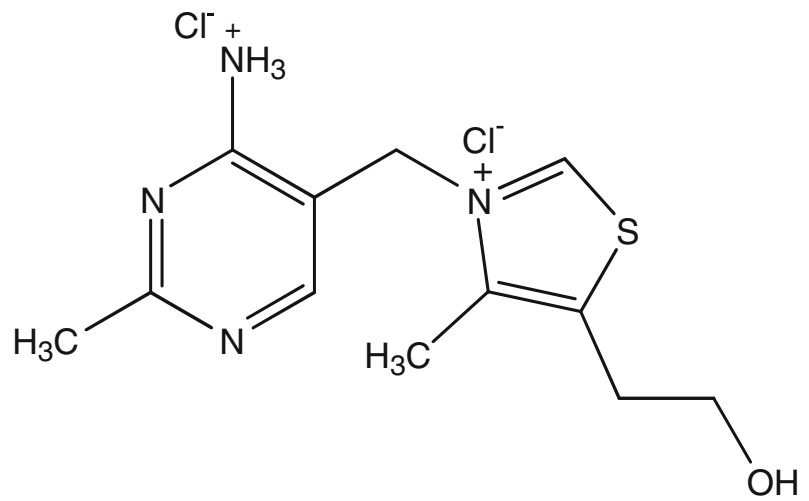

Figure 1. Structure of thiamine hydrochloride.

\section{Experimental}

\subsection{General remarks}

Melting points were determined in open glass capillaries and are uncorrected. IR spectra were determined on a Perkin-Elimer spectrometer. ${ }^{1} \mathrm{H}$ NMR $(300 \mathrm{MHz})$ and ${ }^{13} \mathrm{C}$ NMR (75 MHz) spectra were recorded at room temperature on Varian Inova spectrometer in $\mathrm{CDCl}_{3}$ using TMS as an internal standard. Mass spectra were recorded on an automated Shimadzu QP 5050 mass spectrometer. Reactions were monitored by TLC on aluminum sheets pre-coated with silica gel $60 \mathrm{~F}_{254}$.

\subsection{General procedure for the synthesis of quinoxaline derivatives}

A mixture of aryl-1,2-diamine $\mathbf{1}$ (1 mmol), 1,2-diketone $2(1 \mathrm{mmol})$ and $\mathrm{VB}_{1}(2 \mathrm{~mol} \%)$ in ethanol $(2 \mathrm{~mL})$

*For correspondence 
was stirred at room temperature for appropriate time. The progress of the reaction was monitored by TLC. After completion of the reaction, the reaction mixture was poured into ice cold water. The solid was filtered and purified by column chromatography on silica gel (ethyl acetate/ $n$-hexane) to afford the pure product. The desired pure product(s) were characterized by comparison of their physical data with those known compounds. ${ }^{13-32}$

\subsection{Characterization data of compounds}

3a: mp $127-129^{\circ} \mathrm{C}$ [Lit. ${ }^{19} \mathrm{mp} 126-127^{\circ} \mathrm{C}$ ]; ${ }^{1} \mathrm{H}$ NMR $\left(300 \mathrm{MHz}, \mathrm{CDCl}_{3}\right): \delta=7.29-7.40(\mathrm{~m}, 6 \mathrm{H}, \mathrm{ArH})$, 7.45-7.56 (m, 4 H, ArH), 7.73-7.81 (m, 2 H, ArH), 8.15-8.24 (m, $2 \mathrm{H}, \mathrm{ArH}) ;{ }^{13} \mathrm{C} \mathrm{NMR}\left(75 \mathrm{MHz}, \mathrm{CDCl}_{3}\right)$ : $128.21,128.73,128.96,129.79,129.93,139.02$, 141.22, 153.01; IR (KBr, $\left.\mathrm{Cm}^{-1}\right)$ : 697, 757, 820, 1056, 1216, 1340, 1473, 1540, 1569, 1600, 3060; Calcd for $\mathrm{C}_{20} \mathrm{H}_{14} \mathrm{~N}_{2}$ (282): C 85.08, H 5.00, N 9.92\%. Found: C 85.20, H 5.02, N 9.85\%.

3c: $\mathrm{mp} 192-194^{\circ} \mathrm{C}$ [Lit. $\left.{ }^{19} \mathrm{mp} 193-194^{\circ} \mathrm{C}\right] ;{ }^{1} \mathrm{H}$ NMR $\left(300 \mathrm{MHz}, \mathrm{CDCl}_{3}\right): \delta=7.30-7.43(\mathrm{~m}, 6 \mathrm{H}, \mathrm{ArH})$, $7.53-7.58(\mathrm{~m}, 4 \mathrm{H}, \operatorname{ArH}), 8.29(\mathrm{~d}, J=9.18 \mathrm{~Hz}$, $1 \mathrm{H}, \mathrm{ArH}), 8.53(\mathrm{dd}, J=9.18 \mathrm{~Hz}$ and $2.50 \mathrm{~Hz}, 1 \mathrm{H}$, ArH), $9.07(\mathrm{~d}, J=2.50 \mathrm{~Hz}, 1 \mathrm{H}, \mathrm{ArH}) ;{ }^{13} \mathrm{C} \mathrm{NMR}$ $\left(75 \mathrm{Mhz}, \mathrm{CDCl}_{3}\right)$ : 123.20, 125.50, 128.40, 129.60, 129.70, 129.80, 130.70, 137.91, 138.00; IR (KBr, $\left.\mathrm{Cm}^{-1}\right)$ : 669, 836, 928, 1055, 1215, 1342, 1435, 1475, 1527, 1574, 1618, 3020; Calcd for $\mathrm{C}_{20} \mathrm{H}_{13} \mathrm{~N}_{2} \mathrm{O}_{2}$ (327): C 73.38, H 4.00, N 12.85\%. Found: C 73.18, H 4.12, N $12.75 \%$.

\section{Results and discussion}

As a part of our ongoing program on the development of novel synthetic methods in organic synthesis under mild conditions, ${ }^{36}$ we wish to report a simple and efficient method for the synthesis of quinoxalines in the presence of thiamine hydrochloride $\left(\mathrm{VB}_{1}\right)$ as an inexpensive, non-toxic and metal ion free catalyst at ambient temperature (scheme 1).
To determine the optimum quantity of thiamine hydrochloride, the reaction of $o$-phenylenediamine ( 1 equiv) and benzil (1 equiv) in ethanol was carried out at room temperature using different quantities of catalyst. The use of $2 \mathrm{~mol} \%$ of catalyst resulted in the highest yield in $12 \mathrm{~min}$ (table 1).

In another study, the efficiency of different solvents upon the model reaction was investigated at room temperature and the results are summarized in the table 2 . We observed that in aprotic solvents (entries 1-7, table 2) the product yield was found to be low, but in case of protic solvents (entries $8-10$, table 2) the

Table 1. Optimization quantity of $\mathrm{VB}_{1}$.

\begin{tabular}{lcc}
\hline Entry $^{\mathrm{a}}$ & Catalyst $(\mathrm{mol} \%)$ & Yield $^{\mathrm{b}}(\%)$ \\
\hline 1 & 0 & Trace \\
2 & 1 & 79 \\
3 & 2 & 92 \\
4 & 3 & 91 \\
5 & 4 & 92 \\
\hline
\end{tabular}

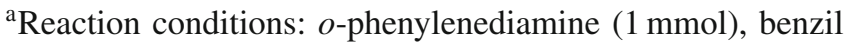
(1 mmol), ethanol (2 ml).

${ }^{\mathrm{b}}$ Yield of pure, isolated product.

Table 2. Optimization of solvent.

\begin{tabular}{llc}
\hline Entry $^{\mathrm{a}}$ & Solvent & Yield $^{\mathrm{b}}(\%)$ \\
\hline 1 & 1,4-Dioxane & 79 \\
2 & Chloroform & 82 \\
3 & DCM & 84 \\
4 & THF & 85 \\
5 & DMF & 86 \\
6 & Acetonitrile & 84 \\
7 & DMSO & 88 \\
8 & Ethanol & 92 \\
9 & Methanol & 90 \\
10 & Water & 89 \\
\hline
\end{tabular}

${ }^{a}$ Reaction conditions: $o$-phenylenediamine $(1 \mathrm{mmol})$, benzil (1 mmol), $\mathrm{VB}_{1}(2 \mathrm{~mol} \%)$, solvent $(2 \mathrm{ml})$.

${ }^{\mathrm{b}}$ Yield of pure, isolated product.

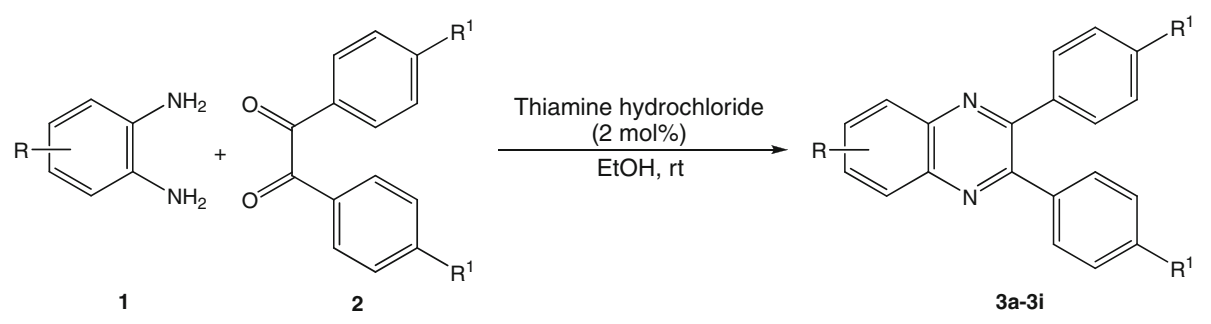

Scheme 1. Synthesis of quinoxaline derivatives. 
reaction rate and product yield was found to be improved comparatively and protic solvent ethanol came out as superior solvent for this reaction.
The efficiency of the $\mathrm{VB}_{1}$ compared to various catalysts was also examined (table 3 ). In this study, it was found that $\mathrm{VB}_{1}$ is an efficient and superior catalyst

Table 3. Comparison of efficiency of various catalysts.

\begin{tabular}{lllcc}
\hline Entry $^{\mathrm{a}}$ & \multicolumn{1}{c}{ Catalyst } & Solvent & Time $(\mathrm{min})$ & Yield $^{\mathrm{b}}(\%)$ \\
\hline 1 & $\mathrm{ZnCl}_{2}(4 \mathrm{~mol} \%)$ & Ethanol & 20 & 82 \\
2 & $\mathrm{I}_{2}(5 \mathrm{~mol} \%)$ & Ethanol & 10 & 91 \\
3 & $\mathrm{Zn}[(\mathrm{L})$ proline $](10 \mathrm{~mol} \%)$ & Acetic acid & 5 & 88 \\
4 & $\mathrm{VB}_{1}(2 \mathrm{~mol} \%)$ & Ethanol & 12 & 92 \\
\hline
\end{tabular}

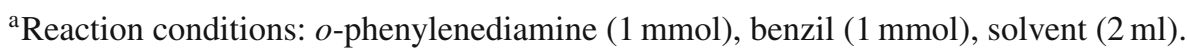

${ }^{b}$ Yield of pure, isolated product.

Table 4. Thiamine hydrochloride catalysed synthesis of quinoxalines.

\begin{tabular}{|c|c|c|c|c|c|}
\hline Entry & 1,2-diamine 1 & 1,2-diketone 2 & Product $^{\mathrm{a}} 3$ & Time (Min) & Yield $(\%)^{\mathrm{b}}$ \\
\hline 1 & & & & 12 & 92 \\
\hline 2 & & & & 14 & 92 \\
\hline 3 & & & & 15 & 87 \\
\hline 4 & & & & 13 & 94 \\
\hline 5 & & & & 14 & 93 \\
\hline
\end{tabular}


Table 4. (continued)

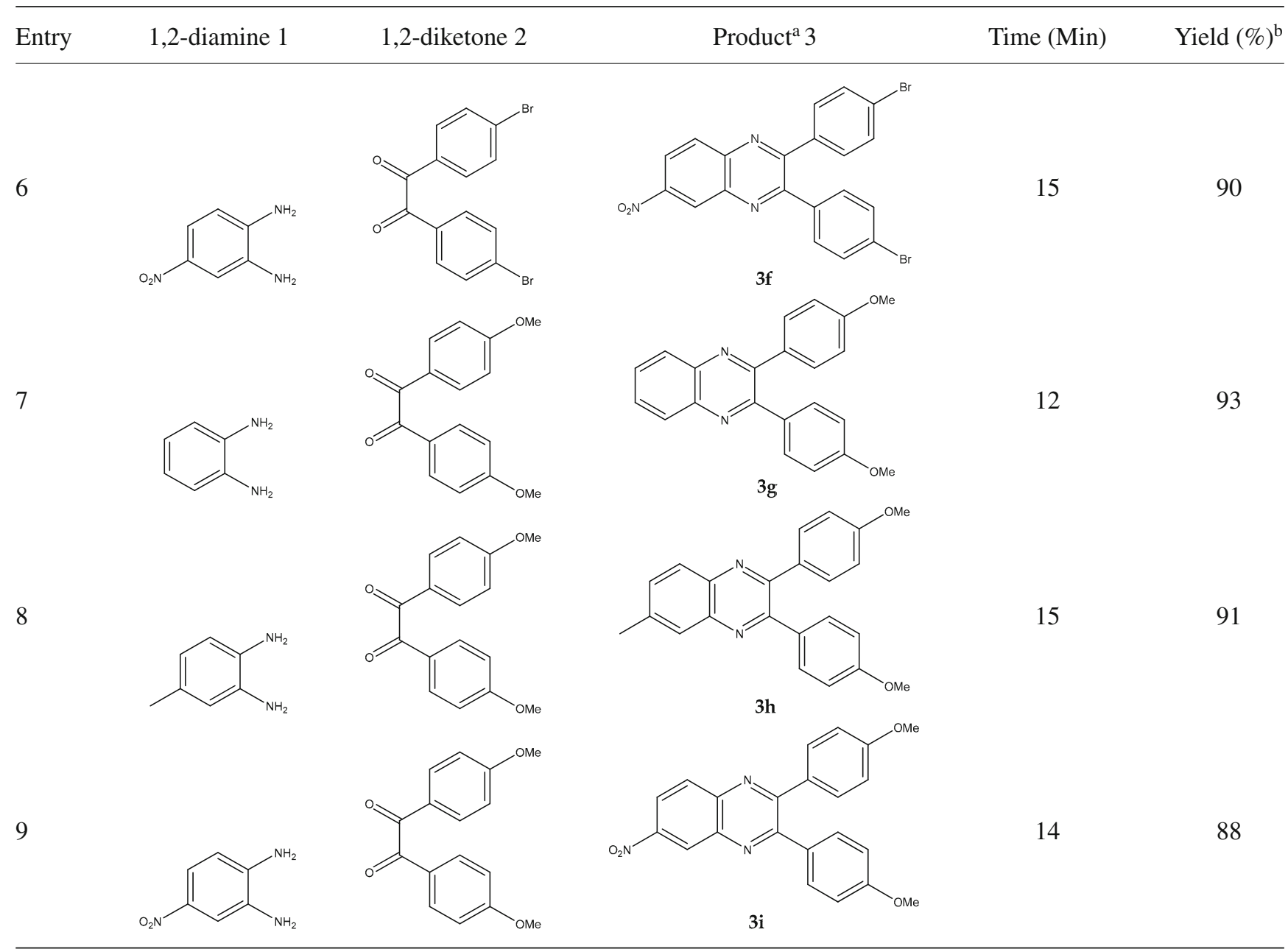

${ }^{a}$ All products were characterized by IR, ${ }^{1} \mathrm{H}$ NMR, ${ }^{13} \mathrm{C}$ NMR spectroscopic data and their m.p. compared with literature values. ${ }^{13-32}$

${ }^{\mathrm{b}}$ Yield of pure, isolated product.

compared to other catalysts with respect to time and yield of product.

To establish the scope of this method various aryl1,2-diamines were reacted with some 1,2-diketones using optimized conditions (table 4). We observed that electronic-donating groups associated with aryl-1,2diamines had no significant effect on the reaction results but electron-withdrawing groups slightly decreased the yields and increased the reaction times.

We have not established an exact mechanism for the formation of this kind of compounds $\mathbf{3}$; however, a plausible mechanism is shown in scheme 2 . The role of the $\mathrm{VB}_{1}$ may be postulated in terms of the $-\mathrm{NH}$ proton of the $\mathrm{VB}_{1}$, leading to its interaction with the

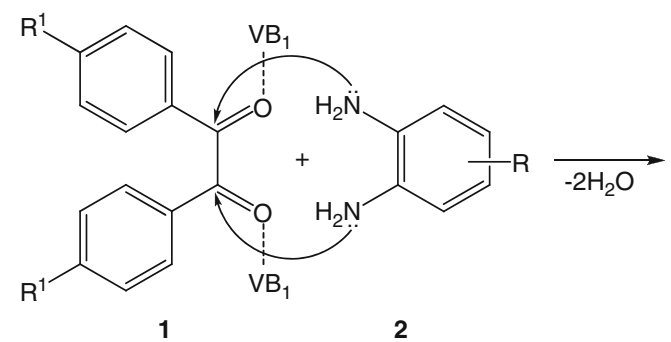<smiles>[TlH]c1ccc(-c2nc3ccccc3nc2-c2ccccc2)cc1</smiles>

Scheme 2. Plausible mechanism for the synthesis of quinoxalines. 
carbonyl oxygen atom of 1,2-diketone, thereby increasing the polarization and promoting the cyclocondensation reaction.

\section{Conclusions}

In conclusion, a reliable, rapid and eco-friendly method for synthesis of quinoxalines has been developed, which involves the use of inexpensive, stable, nontoxic and metal-ion free catalyst. Simple work-up, high yields and mild reaction conditions have made this approach superior over many other previously reported methods.

\section{Acknowledgements}

The authors are thankful to Prof. M S Shingare (Department of Chemistry, Dr. Babasaheb Ambedkar Marathwada University, Aurangabad) and Dr. U B Shinde (Principal, Savitribai Phule Women's Engineering College, Aurangabad) for encouragement to carry out this research work.

\section{References}

1. Sakata G and Makino K 1988 Heterocycles 272481

2. Osdene T S US Patent 3185688 1965; Chem. Abstr. 46 3191

3. Waisser K, Odlerova Z, Beckert R and Mayer R 1989 Pharmazie $\mathbf{4 4} 234$

4. Seitz L E, Suling W J and Reynolds R C 2002 J. Med. Chem. 455604

5. Babichev F S, Grinevich A I, Volovenko Y M, Litvinenko S V, Oshchupkina E V and Dyachenko V Y 1989 Farm. Zh. 53

6. Badran M M, Botros S, El-Gendy A A, Abdou N A, El-Assi H and Salem A 2001 Bull. Pharm. Sci. 24135

7. Hazeldine S T, Polin L, Kushner J, Paluch J, White K, Edelstein M, Palomino E, Corbett T H and Horwitz J P $2001 \mathrm{~J}$. Med. Chem. 441758

8. Hazeldine S T, Polin L, Kushner J, White K, Bouregeois N M, Crantz B, Palomino E, Corbett T H and Horwitz J P 2002 J. Med. Chem. 453130

9. Dailey S, Feast J W, Peace R J, Till I C, Sage S and Wood E L 2001 J. Mater. Chem. 112238

10. Sonawane N D and Rangnekar D W 2002 J. Heterocycl. Chem. 39303
11. Sessler J L, Maeda H, Mizuno T, Lynch V M and Furuta H 2002 J. Am. Chem. Soc. 12413474

12. Kazunobu T, Ryusuke O and Tomohiro M 2002 Chem. Commun. 212

13. Zhao Z, Wisnoski D D, Wallenberg S E, Leister W H, Wang Y and Lindsley C W 2004 Tetrahedron Lett. 45 4873

14. Bhosale R S, Sarda S R, Ardhapure S S, Jadhav W N, Bhusare S R and Pawar R P 2005 Tetrahedron Lett. 46 7183

15. More S V, Sastry M N V and Yao C F 2006 Green Chem. 891

16. Heravi M M, Bakhtiari K, Tehrani M H, Javadi N M and Oskooie H A 2006 ARKIVOC xvi 16

17. Heravi M M, Tehrani M H, Bakhtiari K and Oskooie H A 2007 Catal. Commun. 81341

18. Heravi M M, Bakhtiari K, Bamoharram F F and Tehrani M H 2007 Monatsh. Chem. 138465

19. Heravi M M, Taheri S, Bakhtiari K and Oskooie H A 2007 Catal. Commun. 8211

20. Oskooie H A, Heravi M M, Bakhtiari K and Taheri S 2007 Monatsh. Chem. 138877

21. Srinivas C, Pavankumar C N S, Rao J V and Palaniappan S 2008 Catal. Lett. 1213

22. Raju B C, Theja N D and Kumar J A 2008 Synth. Commun. 39175

23. Potewar T M, Ingale S A and Srinivasan K V 2008 Synth. Commun. 383601

24. Islami M R and Hassani Z 2008 ARKIVOC xv 280

25. Darabi H R, Tahoori F, Aghapoor K, Taala F and Mohsenzadeh F 2008 J. Braz. Chem. Soc. 19 1646

26. Pei-Ying L, Rei-Sheu H, Huey-Min W, Iou-Jiun K and Ling-Ching C 2009 J. Chin. Chem. Soc. 56683

27. Hasaninejad A, Zare A, Shekouhy M and Moosavi-zare A R 2009 E-J. Chem. 6247

28. Shaabani A, Rezayan A H, Behnam M and Heidary M 2009 C. R. Chimie 121249

29. Hasaninejad A, Zare A, Mohammadizadeh M R and Karami Z 2009 J. Iran. Chem. Soc. 6153

30. Wen-Xue G, Hui-Le J, Jiu-Xi C, Fan C, Jin-Chang D and Hua-Yue W 2009 J. Braz. Chem Soc. 201674

31. Bandyopadhyay D, Mukherjee S, Rodriguez R R and Binik B K 2010 Molecules 154207

32. Ibrahim M A 2011 Heterocycles 832689

33. Lei M and Hu M 2009 Tetrahedron Lett. 506393

34. Mandhane P G, Joshi R S, Nagargoje D R and Gill C H 2010 Tetrahedron Lett. $\mathbf{5 1} 3138$

35. Lei M, Ma L and Hu M 2010 Tetrahedron Lett. 51 4186

36. Pawar O B, Chavan F R, Sakate S S and Shinde N D 2010 Chin. J. Chem. 2869 